\title{
Simvastatin induced ferroptosis for triple-negative breast cancer therapy
}

\author{
Xianxian Yao ${ }^{1}$, Ruihong Xie ${ }^{1}$, Yongbin Cao ${ }^{1}$, Jing Tang ${ }^{2}$, Yongzhi Men ${ }^{3}$, Haibao Peng ${ }^{4^{*}}$ (D) and Wuli Yang ${ }^{1 *}$
}

\begin{abstract}
Triple-negative breast cancer (TNBC), a management of aggressive breast cancer, remains an unmet medical challenge. Although a wave of efforts had spurred to design novel therapeutic method of TNBC, unpredictable prognosis with lacking effective therapeutic targets along with the resistance to apoptosis seriously limited survival benefits. Ferroptosis is a non-apoptotic form of cell death that is induced by excessive lipid peroxidation, which provide an innovative way to combat cancer. Emerging evidence suggests that ferroptosis plays an important role in the treatment of TNBC cells. Herein, a novel ferroptosis nanomedicine was prepared by loading simvastatin (SIM), a ferroptosis drug, into zwitterionic polymer coated magnetic nanoparticles ( $\left.\mathrm{Fe}_{3} \mathrm{O}_{4} @ P C B M A\right)$ to improve the therapeutic effect of TNBC. The as-obtained $\mathrm{Fe}_{3} \mathrm{O}_{4} @ P C B M A-S I M$ nanoparticles demonstrated more cytotoxicity against MDA-MB-231 than MCF-7 due to the higher expression of 3-hydroxy-3-methyl-glutaryl-coenzyme A reductase (HMGCR), which demonstrated that statins could effectively kill TNBC. Further experiments showed that SIM could inhibit the expression of HMGCR to downregulate the mevalonate (MVA) pathway and glutathione peroxidase 4 (GPX4), thereby inducing cancer cell ferroptosis. What's more, PCBMA endows $\mathrm{Fe}_{3} \mathrm{O}_{4} @ P C B M A$ longer blood circulation performance to enhance their accumulation at tumor sites. Given that $\mathrm{Fe}_{3} \mathrm{O}_{4}$ have proven for clinical applications by the U.S. Food and Drug Administration (FDA) and SIM could induce cancer cell ferroptosis, the developed $\mathrm{Fe}_{3} \mathrm{O}_{4} @ P C B M A-S I M$ nanosystem would have great potential in clinics for overcoming the drug resistance brought about by apoptotic drugs to cancer cells.
\end{abstract}

Keywords: Triple-negative breast cancer, Ferroptosis, Simvastatin, Long circulation, Controlled release

\section{Introduction}

Breast cancer has the highest fatality rate in women worldwide [1]. Among all types and forms of breast cancer, triple negative breast cancer (TNBC) is the most aggressive and heterogeneous subtype due to lack of estrogen and progesterone receptor expressions, which has been an unmet medical challenge in clinic $[2,3]$. The distinct cellular phenotype with lack of receptor or target makes chemotherapy as an excellent treatment for

\footnotetext{
*Correspondence: haibaopeng@gmail.com; wlyang@fudan.edu.cn

${ }^{1}$ State Key Laboratory of Molecular Engineering of Polymers

\& Department of Macromolecular Science, Fudan University, Shanghai 200433, China

${ }^{4}$ Institute for Translational Brain Research, Fudan University, Shanghai 200032, China

Full list of author information is available at the end of the article
}

TNBC. Nonetheless, the drug resistance and toxic side effects resulting from anti-cancer drugs lead to the failure of cancer chemotherapy, which due to the acquired or intrinsic resistance of cancer cells to apoptosis [4]. Hence, develop effective non-apoptotic treatment strategies has become an urgent need for the treatment of TNBC.

Ferroptosis is a form of iron-dependent cell death induced by excessive lipid peroxidation that distinct from the traditional apoptosis and necrosis [5]. Since the term ferroptosis was proposed in 2012, the unique mechanism of ferroptosis has attracted increasing attention in the field of antitumor therapy [6]. The redoxactive iron $\left(\mathrm{Fe}^{2+}\right)$ is the key elements of ferroptosis and this process characterized by direct or indirect inhibition of glutathione peroxidase 4 (GPX4), lipid repair enzyme, and lipid hydroperoxides (LPO) accumulation original author(s) and the source, provide a link to the Creative Commons licence, and indicate if changes were made. The images or other third party material in this article are included in the article's Creative Commons licence, unless indicated otherwise in a credit line to the material. If material is not included in the article's Creative Commons licence and your intended use is not permitted by statutory regulation or exceeds the permitted use, you will need to obtain permission directly from the copyright holder. To view a copy of this licence, visit http://creativecommons.org/licenses/by/4.0/. The Creative Commons Public Domain Dedication waiver (http://creativeco mmons.org/publicdomain/zero/1.0/) applies to the data made available in this article, unless otherwise stated in a credit line to the data. 
$[7,8]$. Consequently, the intracellular accumulation of LPO leading to impaired cell structure and integrity [9]. The inactivation of GPX4 was produced in the presence of erastin analogs or the direct GPX4 inhibitor [10], such as RSL-3 [11], sorafenib [9], statins [12] and so on. Erastin is a low molecular chemotherapeutics agent and TNBC cells have been reported to be sensitive to erastin-induced ferroptosis using $\mathrm{xCT}$ cystine/glutamate antiporter as a common therapeutic target for TNBC $[13,14]$. To date, several mechanisms leading to iron and reactive oxygen species (ROS) metabolism of ferroptosis have been addressed, but the mechanisms of ferroptosis in breast cancer cells especially in TNBC has hardly been reported [15]. Moreover, it is still challenging to engineer the iron ion delivery system to enhancement the effect of ferroptosis. Therefore, improving the efficiency of iron ion delivery in the process of ferroptosis is of great significance to TNBC patient for cancer treatment and drug design [10].

Statins are a class of low molecular weight drugs that have been approved for clinical control of hypercholesterolemia [16]. Recent study has shown that statins have a potential role in cancer prevention due to their ability to inhibit proliferation, angiogenesis and inflammation $[12,17]$. Joseph et al. reported that statins could lower cholesterol through inhibit 3-hydroxy-3-methyl-glutarylcoenzyme A reductase (HMGCR) to regulate the mevalonate (MVA) pathway [18]. Moreover, it was reported that isopentenyl pyrophosphate participant in the biosynthesis of GPX4 through MVA pathway and HMGCR played a vital role in the synthesis of isopentenyl pyrophosphate $[19,20]$. So far, ferroptosis has been thought to induce cancer cell oxidative damage by controlling the phospholipid hydroperoxide-reducing enzyme GPX4 $[19,21,22]$. Therefore, it will be of great significance if statins could kill TNBC through the way of ferroptosis. However, statins as a kind of small molecule drug is metabolized quickly and few drugs accumulate to the lesion site, severely reducing the effectiveness of treatment. Nanoscale sized materials as an excellent carrier could deliver antitumor drugs to tumor tissues through passively target [23]. But most of nanoparticles rapidly cleared by the reticuloendothelial system as exogenous invaders that affect the percentage of administered nanoparticles reaching in tumor site and limited therapeutic effect $[24,25]$. Therefore, development of novel nanomedicine with long circulation that can enhance the statins accumulation for in vivo TNBC therapy is urgently required.

In this work, we present the construction of zwitterionic polymer coating of ferroferric oxide nanoparticles $\left(\mathrm{Fe}_{3} \mathrm{O}_{4} @ \mathrm{PCBMA}\right)$ to prolong its blood circulation. Simvastatin (SIM), a ferroptosis drug, could be loaded into
$\mathrm{Fe}_{3} \mathrm{O}_{4} @ \mathrm{PCBMA}\left(\mathrm{Fe}_{3} \mathrm{O}_{4} @ \mathrm{PCBMA-SIM}\right)$. MDA-MB-231, a TNBC model, and MCF-7, a normal breast cancer cell model, were used to evaluate the cancer cell killing efficiency. The results showed SIM have more cytotoxicity against MDA-MB-231 than MCF-7, which demonstrated that statins could effectively kill TNBC. In addition, the western blot result illustrated SIM could through inhibit HMGCR to modulate the MVA pathway and deactivate GPX4. With the inherited blood circulation property and ferroptosis effect, the in vivo therapeutic efficiency of $\mathrm{Fe}_{3} \mathrm{O}_{4} @$ PCBMA-SIM was evaluated through building MDA-MB-231 tumor-bearing mice. Our finding highlights that $\mathrm{Fe}_{3} \mathrm{O}_{4} @$ PCBMA-SIM exhibit an excellent tumor suppression, which will open an avenue of TNBC therapy.

\section{Results and discussion}

\section{The preparation of $\mathrm{Fe}_{3} \mathrm{O}_{4} @$ PCBMA}

Carboxybetaine methacrylate (CBMA) was synthesized according to the reported method [26]. Then, we encapsulated $\mathrm{Fe}_{3} \mathrm{O}_{4}$ with poly (carboxybetaine methacrylate) (PCBMA) for enabling longer blood circulation performance [27]. The preparation process of $\mathrm{Fe}_{3} \mathrm{O}_{4} @$ PCBMA was illustrated in Scheme 1. Before encapsulation, carbon-carbon double bond was firstly modified to magnetic nanoparticle, which was proved at the strong peaks centered of $1717 \mathrm{~cm}^{-1}$ by fourier transform infrared spectroscopy (FTIR) (Additional file 1: Fig. S1). Then, 3-aminopropyltriethoxysilanemodified $\mathrm{Fe}_{3} \mathrm{O}_{4}\left(\mathrm{Fe}_{3} \mathrm{O}_{4}\right.$-MPS) nanoparticles were coated with PCBMA network by reflux precipitation polymerization method [28]. Transmission electron microscope (TEM) images of $\mathrm{Fe}_{3} \mathrm{O}_{4}$ and $\mathrm{Fe}_{3} \mathrm{O}_{4} @$ PCBMA with uniformed size displayed spherical morphology and the obvious polymer layer (Fig. 1A, B). In addition, the smooth surface of nanoparticles after coating from the scanning electron microscope also indicated the form of core-shell structure (Fig. 1C, D). It could be seen from the TEM image that the thickness of the zwitterionic polymer layer was about $8 \mathrm{~nm}$. Meanwhile, the hydrate particle size of $\mathrm{Fe}_{3} \mathrm{O}_{4} @ P C B M A$ was a little bigger than $\mathrm{Fe}_{3} \mathrm{O}_{4}$ measured by dynamic light scattering (DLS), which was further prove the successful coating (Fig. 1E). In addition, there was no different of DLS particle size that $\mathrm{Fe}_{3} \mathrm{O}_{4} @$ PCBMA dispersed in aqueous, phosphate buffer solution (PBS), bull serum albumin (BSA) and culture medium Dulbecco Minimum Essential Medium (DMEM), which indicated $\mathrm{Fe}_{3} \mathrm{O}_{4} @$ PCBMA have the good stability (Additional file 1: Fig. S3). Furthermore, the zeta potential of $\mathrm{Fe}_{3} \mathrm{O}_{4} @ \mathrm{PCBMA}$ increased to zero after coating, which due to the equal positive and negative of PCBMA (Fig. 1F). Therefore, 


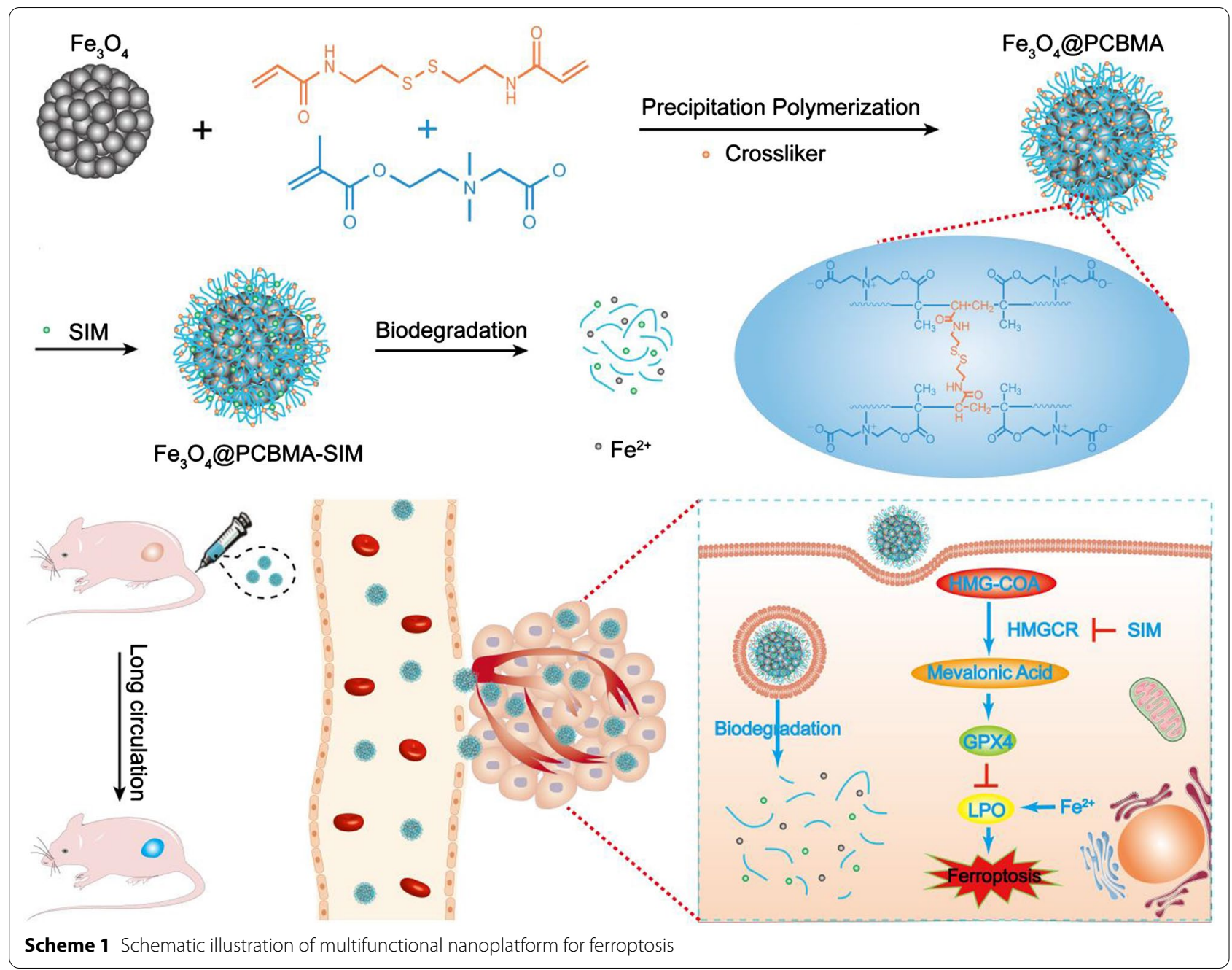

the above results indicated the successful fabrication of $\mathrm{Fe}_{3} \mathrm{O}_{4} @$ PCBMA nanoparticles. And then the SIM loading property was studied. After SIM loading, the morphology and size of the nanoparticles barely changed, indicating the stable of the drug-loaded nanoparticles (Additional file 1: Fig. S2). The FTIR spectra of the $\mathrm{Fe}_{3} \mathrm{O}_{4}$-SIM and $\mathrm{Fe}_{3} \mathrm{O}_{4} @$ PCBM-SIM appeared new bands in the $1300-1000 \mathrm{~cm}^{-1}$ region corresponding to $\mathrm{C}-\mathrm{O}-\mathrm{C}$ of SIM. In addition, there are $11.4 \%$ weight loss of PCBMA at $200-400{ }^{\circ} \mathrm{C}$ and $15.7 \%$ weight loss of SIM at $200-350{ }^{\circ} \mathrm{C}$ showed by thermogravimetric analysis (TGA) of $\mathrm{Fe}_{3} \mathrm{O}_{4} @$ PCBMA-SIM. Moreover, Fig. 1I showed the UV-vis absorbance spectra of the nanoparticles before and after loading SIM. The absorbance peak of $\mathrm{Fe}_{3} \mathrm{O}_{4}$-SIM and $\mathrm{Fe}_{3} \mathrm{O}_{4} @$ PCBMA-SIM at $238 \mathrm{~nm}$ were attributed to the SIM characteristic absorbance, which indicated the SIM successful loading. These results suggested the successful fabrication of $\mathrm{Fe}_{3} \mathrm{O}_{4} @$ PCBM-SIM through PCBMA coating and SIM loading.
The biodegradation and controlled drug release

A sustainable and efficient fenton reaction nanoplatform for tumor therapy was developed based on $\mathrm{Fe}_{3} \mathrm{O}_{4}$ nanoparticle. As described in Fig. 2A, $\mathrm{Fe}_{3} \mathrm{O}_{4} @$ PCBMA-SIM nanoparticles could trigger more ROS generation in response to tumor microenvironment and release large amounts of $\mathrm{Fe}^{2+}$ for further promoting cancer cell death. In addition, the concentration of glutathione (GSH) in cancer cell was ranging from 2 to $10 \mathrm{mM}$ and the $\mathrm{pH}$ was 6.5-5.0 in lysosomes of cancer cell and 7.4 in normal tissues [29,30]. Therefore, the biodegradability of $\mathrm{Fe}_{3} \mathrm{O}_{4}$ and $\mathrm{Fe}_{3} \mathrm{O}_{4} @$ PCBMA were investigated. Certified by the inductively coupled plasma spectrometry (ICPAES), the degradation property of $\mathrm{Fe}_{3} \mathrm{O}_{4} @ \mathrm{PCBMA}$ were increased by the increased concentrations of GSH and as the $\mathrm{pH}$ value of PBS decreased. After $96 \mathrm{~h}$, the Fe concentration was only $1.8 \mu \mathrm{g} / \mathrm{mL}$ in the $\mathrm{pH} 5.0$ buffer solution with GSH of $10 \mathrm{mM}$ and there was only few Fe in neutral environment with GSH of $10 \mathrm{mM}$, implying that $\mathrm{Fe}_{3} \mathrm{O}_{4} @$ PCBMA could be decomposed into iron ions (Fig. 2B). 

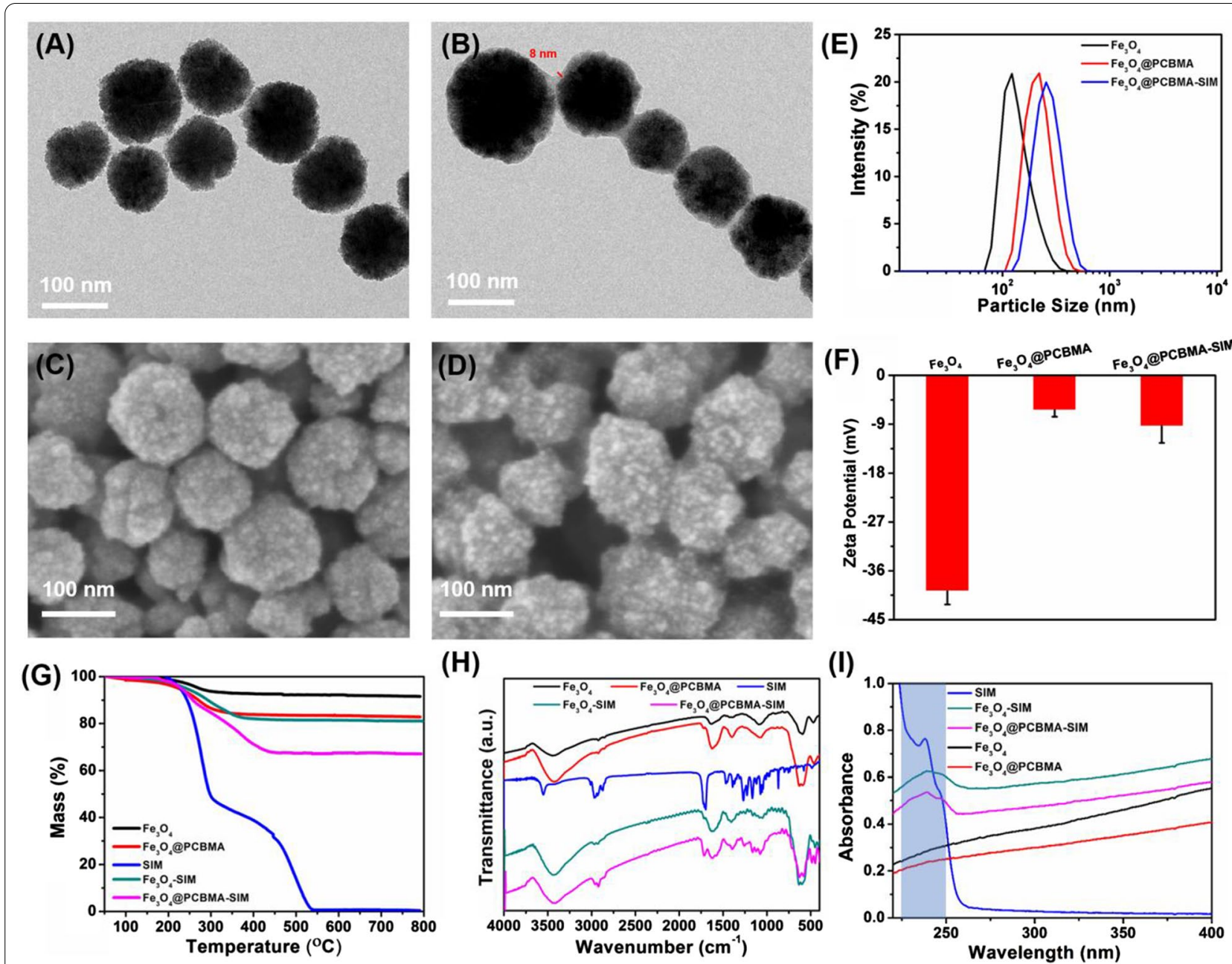

(H)

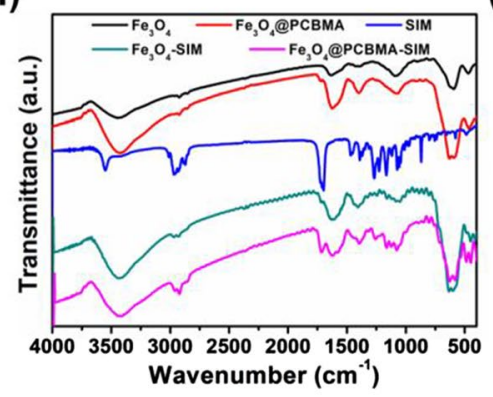

(l)

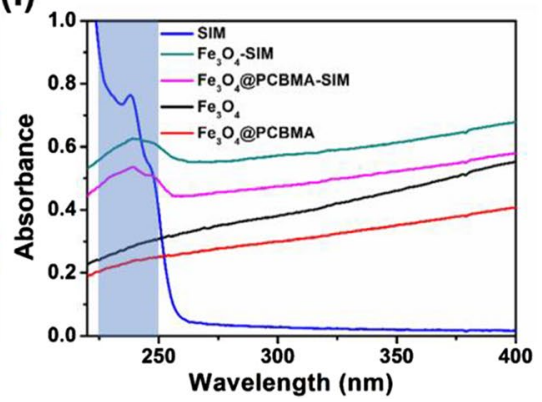

Fig. 1 TEM images of $\mathrm{Fe}_{3} \mathrm{O}_{4}(\mathbf{A})$ and $\mathrm{Fe}_{3} \mathrm{O}_{4} @ P C B M A(\mathbf{B})$ nanoparticles; $\mathrm{SEM}$ images of $\mathrm{Fe}_{3} \mathrm{O}_{4}(\mathbf{C})$ and $\mathrm{Fe}_{3} \mathrm{O}_{4} @ P C B M A$ nanoparticles (D); DLS diameters of $\mathrm{Fe}_{3} \mathrm{O}_{4}, \mathrm{Fe}_{3} \mathrm{O}_{4} @ P C B M A$, and $\mathrm{Fe}_{3} \mathrm{O}_{4} @ P C B M A-S I M$ nanoparticles (E); Zeta potential of $\mathrm{Fe}_{3} \mathrm{O}_{4}, \mathrm{Fe}_{3} \mathrm{O}_{4} @ P C B M A$, and Fe $\mathrm{O}_{4} @ P C B M A-S I M$ nanoparticles (F); TGA analysis of $\mathrm{Fe}_{3} \mathrm{O}_{4}, \mathrm{Fe}_{3} \mathrm{O}_{4} @ P C B M A, S I M, \mathrm{Fe}_{3} \mathrm{O}_{4}-\mathrm{SIM}$ and Fe $\mathrm{O}_{4} @ P C B M A-S I M$ nanoparticles measured in air (G); FT-IR spectra of Fe $\mathrm{O}_{4}, \mathrm{Fe}_{3} \mathrm{O}_{4} @$ PCBMA, SIM, Fe $\mathrm{O}_{4}$-SIM and Fe $\mathrm{O}_{4} @ P C B M A-S I M$ nanoparticles (H); UV-vis spectra of SIM, $\mathrm{Fe}_{3} \mathrm{O}_{4}-\mathrm{SIM}_{1} \mathrm{Fe}_{3} \mathrm{O}_{4} @ P C B M A-\mathrm{SIM}_{1} \mathrm{Fe}_{3} \mathrm{O}_{4}$ and Fe $\mathrm{Fe}_{3} @ P C B M A$ nanoparticles (I)

The degradation property of $\mathrm{Fe}_{3} \mathrm{O}_{4}$ was similar to $\mathrm{Fe}_{3} \mathrm{O}_{4} @$ PCBMA and the Fe concentration $(2.3 \mu \mathrm{g} / \mathrm{mL})$ in the $\mathrm{pH}$ 5.0 buffer solution with GSH of $10 \mathrm{mM}$ was higher than $\mathrm{Fe}_{3} \mathrm{O}_{4} @ \mathrm{PCBMA}$, which due to the existence of PCBMA in the shell (Additional file 1: Fig. S4). Therefore, SIM would be released faster after phagocytosis by cancer cells in theory.

To evaluate drug release behavior, we first measured the drug loading ratios of SIM by UV-vis absorbance spectra at $238 \mathrm{~nm}$. The UV-vis calculated that SIM was loaded in $\mathrm{Fe}_{3} \mathrm{O}_{4}$ and $\mathrm{Fe}_{3} \mathrm{O}_{4} @$ PCBMA with contents of 10 and $15 \%$ respectively. Then the mass ratio of nanoparticles to SIM was deliberately controlled to $10 \%$ for the consistency of subsequent experiments. Afterwards, the drug release property of $\mathrm{Fe}_{3} \mathrm{O}_{4}$-SIM and $\mathrm{Fe}_{3} \mathrm{O}_{4} @$ PCBMA-SIM nanoparticles were studied by dispersing the nanoparticles into glutathione (GSH, $10 \mathrm{mM}$ ). As shown in Fig. 2C, the SIM releasing amount increased with incubating time and there were about $70 \%$ SIM released from $\mathrm{Fe}_{3} \mathrm{O}_{4}$-SIM and 55\% SIM released from $\mathrm{Fe}_{3} \mathrm{O}_{4} @$ PCBMA-SIM over $24 \mathrm{~h}$, indicating a distinct rapid release behavior. Therefore, $\mathrm{Fe}_{3} \mathrm{O}_{4}$-SIM and $\mathrm{Fe}_{3} \mathrm{O}_{4} @$ PCBMA-SIM could release SIM under the microenvironments of cancer cell.

In-vitro cytotoxicity and cell uptake of $\mathrm{Fe}_{3} \mathrm{O}_{4} @ \mathrm{PCBMA-SIM}$ It is well known that TNBC is very difficult to treatment owing to its heterogeneity, molecular variability, and stemness [31]. It is very significant to develop sufficient drug to kill TNBC. The viability of breast cancer cell (MCF-7) and triple-negative breast cancer cell 
(A)

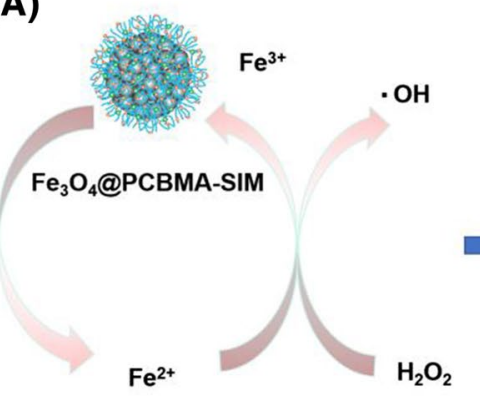

(C)

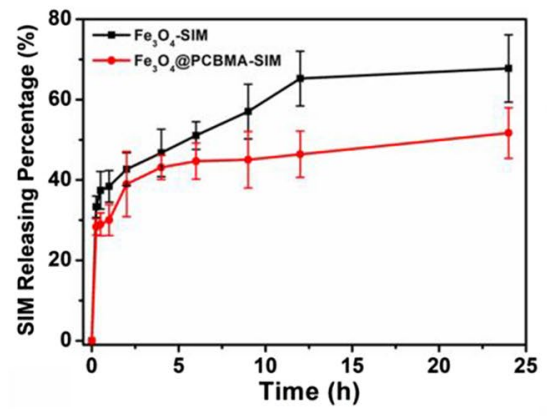

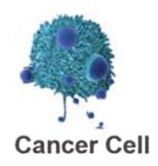

$\cdot \mathrm{OH} \downarrow \circ \mathrm{SIM}$

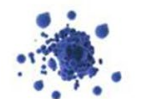

Cancer Cell Death
(D)

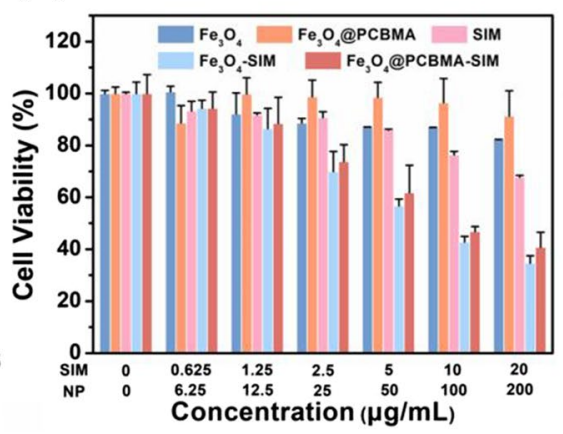

(B)

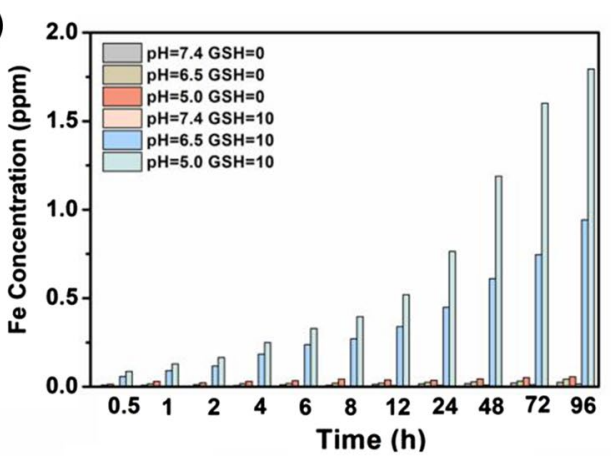

(E)

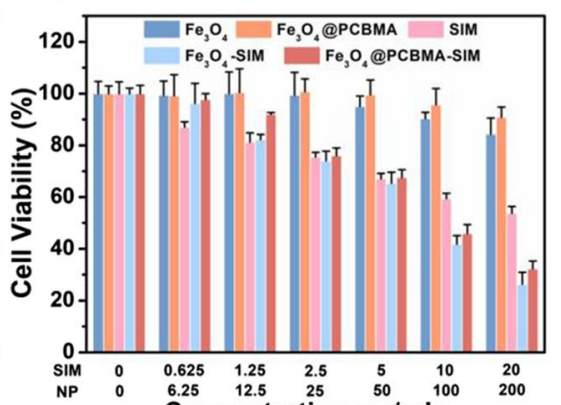

(F) $\mathrm{Fe}_{3} \mathrm{O}_{4} @ \mathrm{PCBMA}$ SIM $\mathrm{Fe}_{3} \mathrm{O}_{4}-\mathrm{SIM}$ $\mathrm{Fe}_{3} \mathrm{O}_{4} @ P C B M A-S I M$
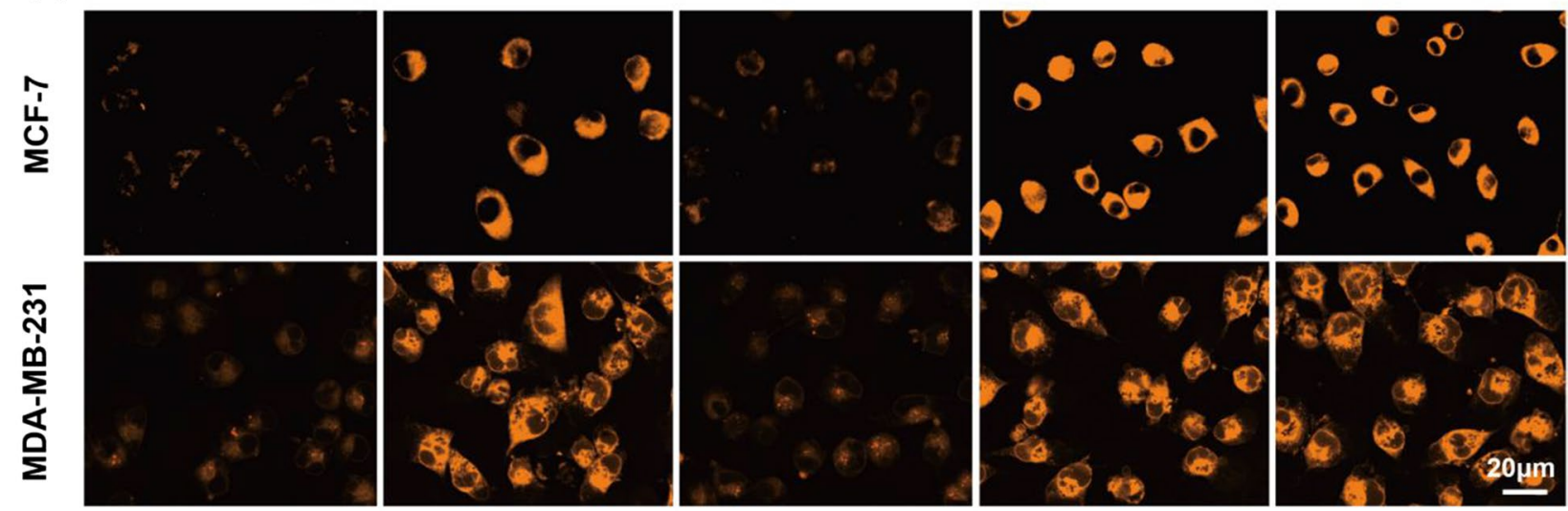

Fig. 2 Schematic illustration of $\mathrm{Fe}_{3} \mathrm{O}_{4} @ P C B M A-S I M$ nanoparticles killing cancer cells $(\mathbf{A})$; The degradation property of Fe $\mathrm{O}_{4} @ P C B M A$ nanoparticles dispersed in different concentrations of GSH (0 mM and $10 \mathrm{mM}$ ) and pH values $\left(5.0,6.5\right.$ and 7.4) (B); Cumulative SIM releasing from Fe ${ }_{3} \mathrm{O}_{4}$-SIM and $\mathrm{Fe}_{3} \mathrm{O}_{4} @ \mathrm{PCBMA}-\mathrm{SIM}$ nanoparticles dispersed in $10 \mathrm{mM} \mathrm{GSH}(\mathbf{C})$; Cell viability of the MCF-7 (D) and MDA-MB-231 (E) cells after $48 \mathrm{~h}$ incubation

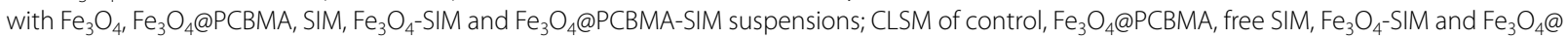
PCBMA-SIM nanoparticles after uptake by MCF-7 and MDA-MB-231 cells (F)

(MDA-MB-231) treated with $\mathrm{Fe}_{3} \mathrm{O}_{4} @$ PCBMA-SIM were investigated in this study adopting the cell counting kit-8 (CCK-8) assay. Before in vitro cytotoxicity experience, we first studied the biocompatibility. As shown in Fig. 2D, E, the viability of two cancer cells cultured in the presence of $\mathrm{Fe}_{3} \mathrm{O}_{4}$ were indicated slightly toxicity. After encapsulate PCBMA, there were negligible cytotoxicity of $\mathrm{Fe}_{3} \mathrm{O}_{4} @$ PCBMA even though the concentration of nanoparticles were $200 \mu \mathrm{g} / \mathrm{mL}$. In addition, free $\mathrm{SIM}, \mathrm{Fe}_{3} \mathrm{O}_{4}$-SIM and $\mathrm{Fe}_{3} \mathrm{O}_{4} @ \mathrm{PCBMA}-\mathrm{SIM}$ displayed a concentrationdependent cytotoxicity against both MCF-7 and MDAMB-231 cells, and free SIM, $\mathrm{Fe}_{3} \mathrm{O}_{4}$-SIM and $\mathrm{Fe}_{3} \mathrm{O}_{4} @$ PCBMA-SIM were more cytotoxic to MDA-MB-231 cells than to MCF-7 cells, which proved that $\mathrm{Fe}_{3} \mathrm{O}_{4} @ P C B M A-$ SIM could effectively kill TNBC. For example, the cell viability of MDA-MB-231 was $54 \%$ after treated with free SIM $(20 \mu \mathrm{g} / \mathrm{mL})$, which was lower than that MCF-7 cells $(68 \%)$. The cytotoxicity to MDA-MB-231 (32\%) still 
higher than to MCF-7 cells (41\%) after loaded to $\mathrm{Fe}_{3} \mathrm{O}_{4}$, probably due to the higher contribution of SIM and $\mathrm{Fe}_{3} \mathrm{O}_{4}$ to the system than free SIM. However, $\mathrm{Fe}_{3} \mathrm{O}_{4}$-SIM exhibited slightly higher cytotoxicity to two cancer cells than $\mathrm{Fe}_{3} \mathrm{O}_{4} @ \mathrm{PCBMA}-\mathrm{SIM}$, which was due to the shell protection of PCBMA. In addition, the cell viability of MCF-7 cells and MDA-MB-231 cells with ferrous sulfate were measured. The cell viability was no obvious difference after ferrous sulfate added compared to control group whether ferrous sulfate added to MCF-7 cells or MDAMB-231 cells, which confirmed that the iron ion has no cytotoxicity against MDA-MB-231 (Additional file 1: Fig. S5) and MCF-7 (Additional file 1: Fig. S6). Therefore, it can be concluded that SIM was higher sensitive to MDAMB-231 and $\mathrm{Fe}_{3} \mathrm{O}_{4} @$ PCBMA-SIM was an excellent strategy for the treatment of TNBC.

Further, the phagocytosis property of nanoparticles was investigated using FerroOrange as iron ion detection reagent in cells [32]. As shown in Fig. 2F, the orange fluorescence were obvious when MCF-7 and MDA-MB-231 cells treated with $\mathrm{Fe}_{3} \mathrm{O}_{4}, \mathrm{Fe}_{3} \mathrm{O}_{4}$-SIM and $\mathrm{Fe}_{3} \mathrm{O}_{4} @ \mathrm{PCBMA}$ SIM nanoparticles, whereas few orange fluorescence in control group and free SIM group, indicating that enormous amount of $\mathrm{Fe}^{2+}$ ions generated via nanoparticles. Therefore, $\mathrm{Fe}_{3} \mathrm{O}_{4} @$ PCBMA-SIM nanoparticles could be degraded into iron ion after phagocytosed by cancer cells.

\section{In-vitro reactive oxygen species (ROS) generation}

It was well-known that ROS could generated by ferrous ions via fenton reaction. To visually observe the generation of ROS, dichlorofluorescein diacetate (DCFH-DA) was used as a fluorescent probe to detect the generation of ROS [33]. As shown in Fig. 3A, MCF-7 and MDA-MB-231 cells showed weak fluorescence intensity incubated with $\mathrm{Fe}_{3} \mathrm{O}_{4} @ P C B M A$ due to the insufficient concentration of $\mathrm{H}_{2} \mathrm{O}_{2}$ to produce a small amount of ROS. The fluorescence slightly increased after incubation with free SIM, on account of the production of SIM through the MVA pathway. After treatment with
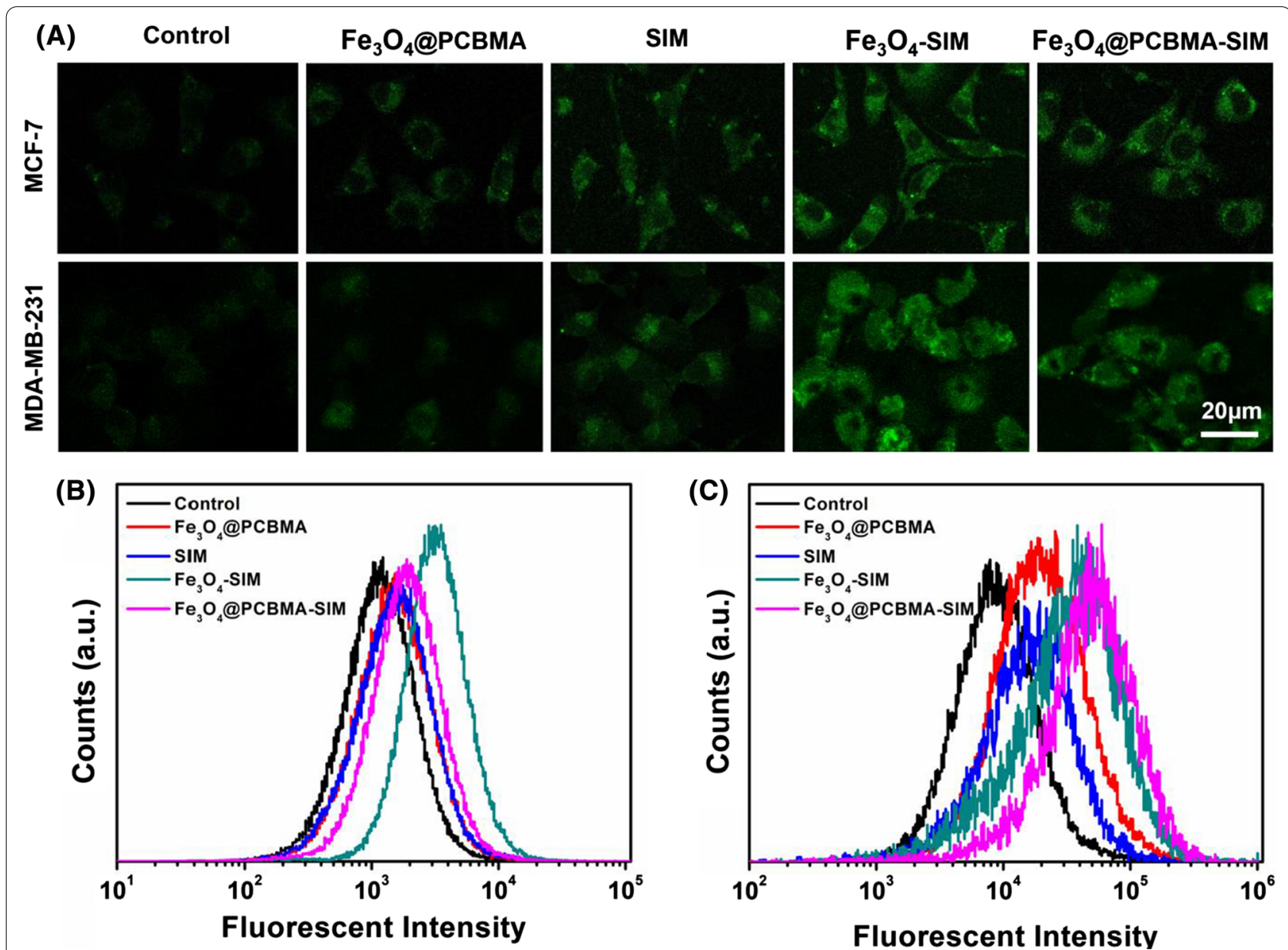

Fig. $3 \mathrm{CLSM}(\mathbf{A})$ and flow cytometry analysis (B, C) of reactive oxygen species (ROS) generation in MCF-7 and MDA-MB-231 cells 
$\mathrm{Fe}_{3} \mathrm{O}_{4}$-SIM and $\mathrm{Fe}_{3} \mathrm{O}_{4} @$ PCBMA-SIM, the intensity of green fluorescence of cells was significantly enhanced. In addition, $\mathrm{Fe}_{3} \mathrm{O}_{4}$-SIM group and $\mathrm{Fe}_{3} \mathrm{O}_{4} @$ PCBMA-SIM group exhibit stronger fluorescence intensity than free SIM group from the analysis of flow cytometry (Fig. 3B, C) both in MCF-7 cells and MDA-MB-231 cells, which indicated the enhanced production of ROS in cancer cells induced by $\mathrm{Fe}_{3} \mathrm{O}_{4}$-SIM or $\mathrm{Fe}_{3} \mathrm{O}_{4} @$ PCBMA-SIM.

\section{In-vitro mechanism of ferroptosis}

Statins, a small molecule potent inhibitors of the 3-hydroxy-3-methylglutaryl-coenzyme A reductase (HMGCR), could affect the MVA pathway to control the biosynthesis of cholesterol [34]. This process in suppression of some metabolites and inactivation of GPX4
$[12,35]$. For further study the mechanism of ferroptosis induced by $\mathrm{Fe}_{3} \mathrm{O}_{4} @ \mathrm{PCBMA}-\mathrm{SIM}$, western blot was used to study the MVA pathway. As shown in Fig. 4B, C, the expression of GPX4 and HMGCR protein in MCF-7 cells and MDA-MB-231 cells were influenced by the addition of SIM and $\mathrm{Fe}_{3} \mathrm{O}_{4}$. For HMGCR protein, both $\mathrm{Fe}_{3} \mathrm{O}_{4} @$ PCBMA and SIM groups all decreased its expression compared with the control group and this lowering effect was obviously in MCF-7 cells (Fig. 4E, G). However, the expression of GPX4 in MCF-7 cells after treated with $\mathrm{Fe}_{3} \mathrm{O}_{4} @ P C B M A, S I M$ and $\mathrm{Fe}_{3} \mathrm{O}_{4}$-SIM were almost no difference and the expression of GPX4 protein decreased obviously after treated with $\mathrm{Fe}_{3} \mathrm{O}_{4} @$ PCBMA and SIM, and further decreased after the addition of $\mathrm{Fe}_{3} \mathrm{O}_{4}$-SIM and $\mathrm{Fe}_{3} \mathrm{O}_{4} @$ PCBMA-SIM in MDA-MB-231 cells, which

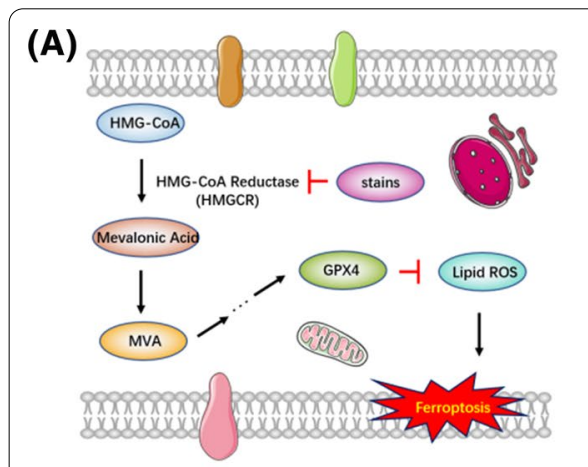

(D)

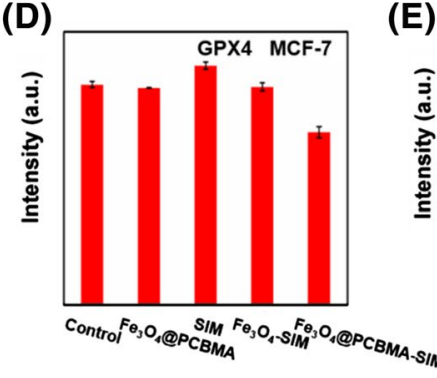

(H)

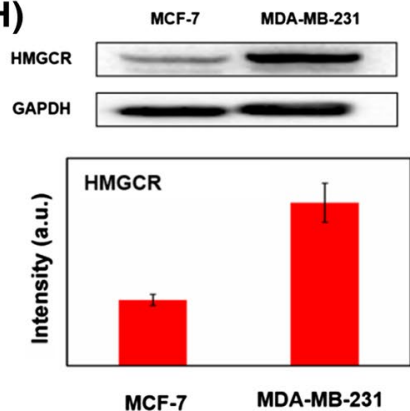

(B)

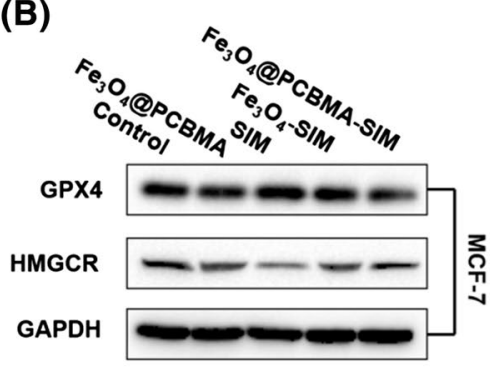

(C)

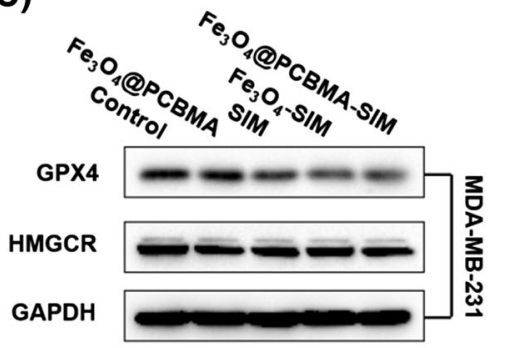

(E)
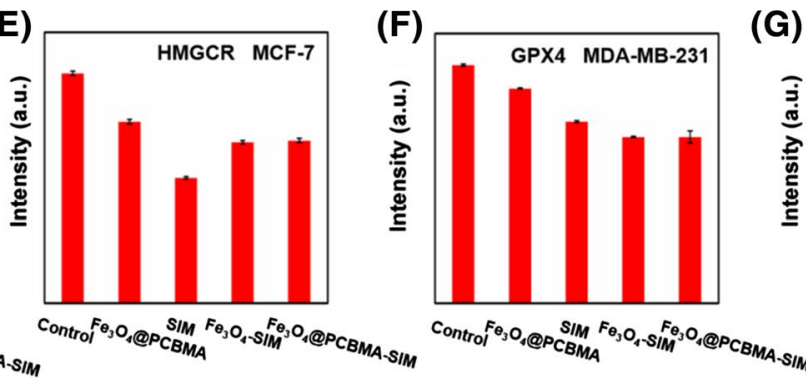

(G)

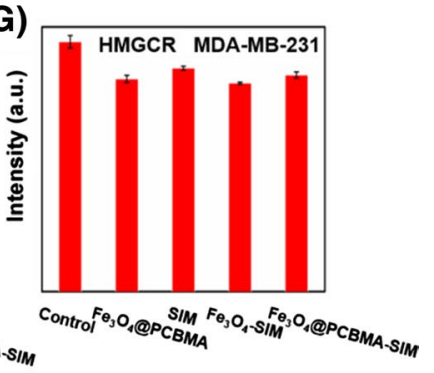

Fig. 4 Schematic illustration of ferroptosis mechanism (A); The GPX4 and HMGCR protein expression of MCF-7 cells after treated with Fe $\mathrm{O}_{4} @$ PCBMA, SIM, $\mathrm{Fe}_{3} \mathrm{O}_{4}-\mathrm{SIM}$ and $\mathrm{Fe}_{3} \mathrm{O}_{4} @ P C B M A-\mathrm{SIM}(\mathbf{B}, \mathbf{D}, \mathbf{E})$; The GPX4 and HMGCR protein expression of MDA-MB-231 cells after treatment with $\mathrm{Fe}_{3} \mathrm{O}_{4} @ P C B M A, \mathrm{SIM}, \mathrm{Fe}_{3} \mathrm{O}_{4}$-SIM and Fe $\mathrm{O}_{4} @ P C B M A-\mathrm{SIM}(\mathbf{C}, \mathbf{F}, \mathbf{G})$; The HMGCR protein expression of MCF-7 cells and MDA-MB-231 cells and the corresponding intensity $(\mathbf{H})$; Flow cytometry analysis of lipid hydroperoxides (LPO) generation in MCF-7 (I) and MDA-MB-231 cells (J) 
was due to the synergy effect of SIM and $\mathrm{Fe}_{3} \mathrm{O}_{4}$ (Fig. 4D, F). In addition, we have also measurement the amount of HMGCR protein in two cancer cells to study the reason of this phenomenon. As shown in Fig. $4 \mathrm{H}$, the HMGCR protein expression in MDA-MB-231 cells was much higher than in MCF-7 cells, which accounted for the unconspicuous inhibition effect of HMGCR protein. Therefore, the above results show that ferroptosis could occur through MVA pathway to inactivation of GPX4 in TNBC.

Moreover, the inactivation of GPX4 would inhibit the conversion of lipid peroxides into lipid alcohols and the lipid hydroperoxides (LPO) can be used as an important indicator of the ferroptosis [36]. Therefore, the inactivation of GPX4 could promote the accumulation of lipid peroxide level. As shown in Fig. 4I, J, the fluorescence

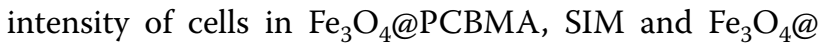
PCBMA-SIM groups showed stronger than that of the control group, which indicated more LPO production after nanodrugs effect. Unlike ROS, the basic LPO in MDA-MB-231 cells was higher than in MCF-7 cells and MDA-MB-231 cells produce more LPO than MCF-7 cells after incubation, which could account for the more cytotoxic of $\mathrm{Fe}_{3} \mathrm{O}_{4} @$ PCBMA-SIM to MDA-MB-231 cells than to MCF-7 cells. Therefore, we could conclude that this nanoplatform could inhibit the expression of HMGCR to downregulate the mevalonate (MVA) pathway and glutathione peroxidase 4 (GPX4), thereby producing more LPO to induce cancer cell ferroptosis, as schematically illustrated in Fig. 4A.

\section{Pharmacokinetics and biodistribution}

Nanoparticles could achieve better therapeutic efficacy compared with free drugs due to the high permeability and retention effect of solid tumors [37]. Nevertheless, the unsatisfactory tumor accumulation of nanoparticles is due to the undesirable blood circulation [31]. Therefore, design nanomedicine with prolonged blood circulation property is very important. In this study, we fabricated zwitterionic polymer coating of magnetic nanoparticles for enhancing their blood retention and effectively improved the therapeutic effect of TNBC. MDA-MB-231 tumor-bearing mice were used to study the accumulation property of $\mathrm{Fe}_{3} \mathrm{O}_{4} @$ PCBMA in vivo. After 12, 24 and $48 \mathrm{~h}$ injection, visceral organs and tumors were taken out. Then, Fe content were measured using ICPAES. The accumulation of $\mathrm{Fe}_{3} \mathrm{O}_{4} @ P C B M A$ and $\mathrm{Fe}_{3} \mathrm{O}_{4}$ in tumors at $12 \mathrm{~h}$ post injection were $12.6 \pm 2.1 \% \mathrm{ID} / \mathrm{g}$ and $5.2 \pm 1.2 \% \mathrm{ID} / \mathrm{g}$ respectively (Additional file 1 : Fig. S7). As shown in Fig. 5A, the accumulation of $\mathrm{Fe}_{3} \mathrm{O}_{4} @ P C B M A$ just decreased to $11.1 \pm 4.8 \% \mathrm{ID} / \mathrm{g}$ at the tumor site after $24 \mathrm{~h}$ injection and the accumulation of $\mathrm{Fe}_{3} \mathrm{O}_{4}$ reduced to $3.1 \pm 3.9 \% \mathrm{ID} / \mathrm{g}$, which indicated that there are more
$\mathrm{Fe}_{3} \mathrm{O}_{4} @ \mathrm{PCBMA}$ intratumor accumulation than $\mathrm{Fe}_{3} \mathrm{O}_{4}$. Interestingly, the accumulation of $\mathrm{Fe}_{3} \mathrm{O}_{4} @ \mathrm{PCBMA}$ was still $8.1 \pm 0.7 \% \mathrm{ID} / \mathrm{g} 4$ at $48 \mathrm{~h}$ post injection (Additional file 1: Fig. S8). Moreover, in addition to the decreased nanoparticles at the tumor site, the residual amounts of nanoparticles in liver and lung also significantly reduced, while the uptake increased in kidney within $24 \mathrm{~h}$, indicating the better metabolic performance of $\mathrm{Fe}_{3} \mathrm{O}_{4} @ \mathrm{PCBMA}$.

For further study the nanoparticle retention in blood, pharmacokinetics studies were performed for $\mathrm{Fe}$ content measurement using ICP-AES. As shown in Fig. 5B, $\mathrm{Fe}_{3} \mathrm{O}_{4}$ in blood was decreased to $3.9 \pm 2.6 \% \mathrm{ID} / \mathrm{mL}$ after $24 \mathrm{~h}$ intravenous injection. In contrast, about $15.1 \pm 4.1 \%$ $\mathrm{ID} / \mathrm{mL}$ of $\mathrm{Fe}_{3} \mathrm{O}_{4} @ P C B M A$ were still in blood circulation. Moreover, there was 9.9 $\pm 7.1 \% \mathrm{ID} / \mathrm{mL}$ of $\mathrm{Fe}_{3} \mathrm{O}_{4} @$ PCBMA nanoparticles stayed in blood after $48 \mathrm{~h}$ injection. A significant increase indicated that zwitterionic polymer could prolong blood circulation time of nanoparticles in vivo and it also proved the successfully synthesis of $\mathrm{Fe}_{3} \mathrm{O}_{4} @ P C B M A$.

\section{In vivo antitumor combined therapy efficacy}

Encouraged by the excellent tumor accumulation of $\mathrm{Fe}_{3} \mathrm{O}_{4} @ \mathrm{PCBMA}$, the in vivo antitumor efficacy was then performed on MDA-MB-231 tumor models. All mice were divided into five groups $(n=5)$. As shown in Fig. $5 \mathrm{C}$, there is no obvious change in tumor size between $\mathrm{Fe}_{3} \mathrm{O}_{4} @$ PCBMA group and control group, while tumors grew slower in SIM and $\mathrm{Fe}_{3} \mathrm{O}_{4}$-SIM than control group. When encapsulated with PCBMA, the growth of tumors suppressed in 22 days and the antitumor rate was $76.1 \%$, which indicated that TNBC could be suppressed under ferroptosis. The most impressive thing is that no significant weight loss was seen in all groups of mice (Fig. 5D), indicating that the safety of $\mathrm{Fe}_{3} \mathrm{O}_{4} @$ PCBMA-SIM. The tumor photos in all groups were consistent with the tumor growth curves. To further study the systemic toxicity of the nanoparticles, all mice were sacrificed at the 22th day treatment and the main organs (liver, spleen, heart, lung, and kidney) were removed and co-stained by hematoxylin and eosin $(\mathrm{H} \& \mathrm{E})$. As shown in Fig. 6D, there were no obvious tissue damages and noticeable pathological changes in the five groups, which indicated that nanoparticles were possess biosafety and could be an effective nanoplatform for cancer treatment. In addition, TUNEL assay results showed that $\mathrm{Fe}_{3} \mathrm{O}_{4} @$ PCBMA-SIM group had the highest mortality in vivo tumor treatment and it is consistent with its good antitumor inhibition effect (Additional file 1: Fig. S9). In addition, blood biochemistry and routine blood tests were used to tasty the of $\mathrm{Fe}_{3} \mathrm{O}_{4} @ \mathrm{PCBMA}$. As shown in Fig. 6A-C, there was no obvious difference of blood indices compared $\mathrm{Fe}_{3} \mathrm{O}_{4}$ 

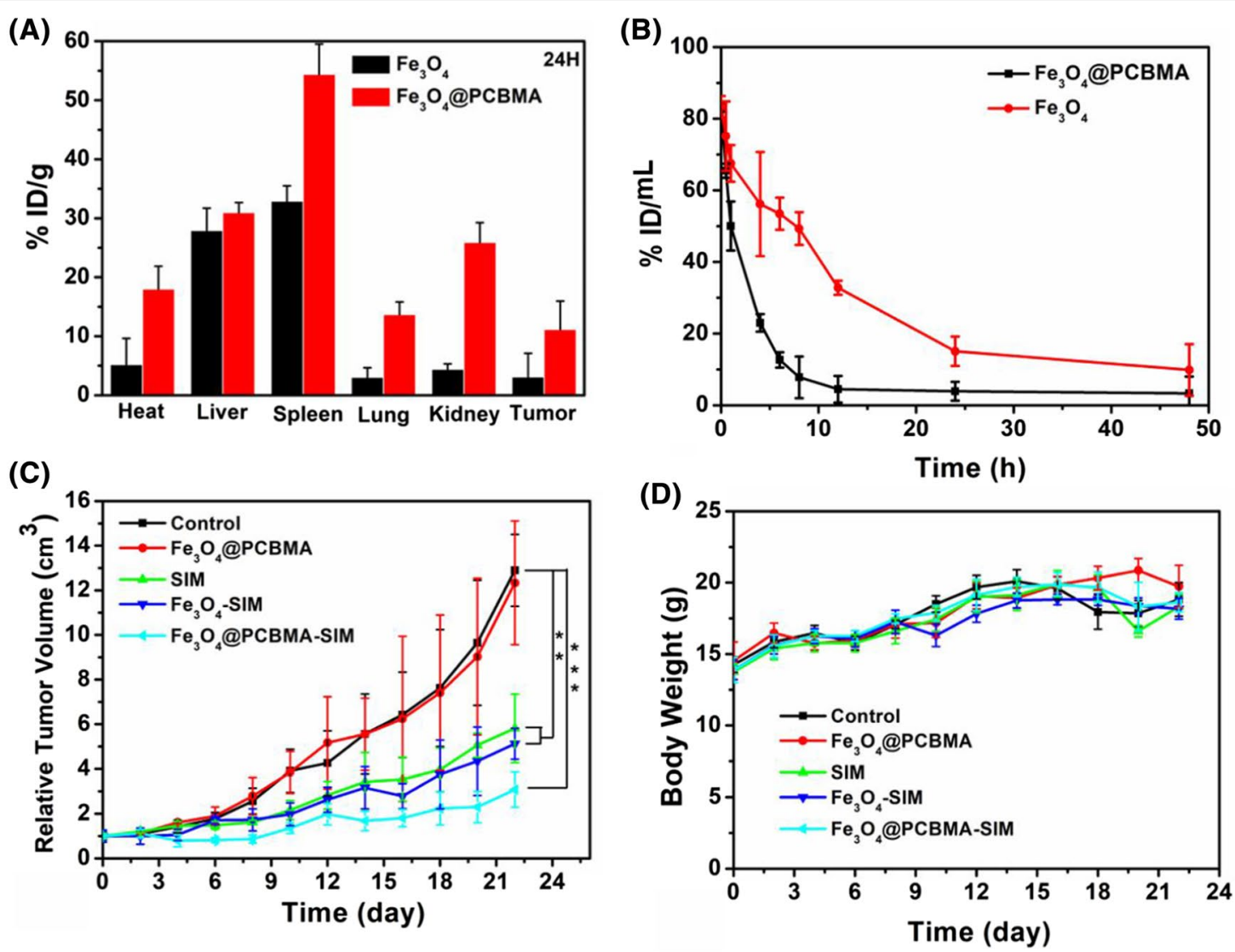

(E)

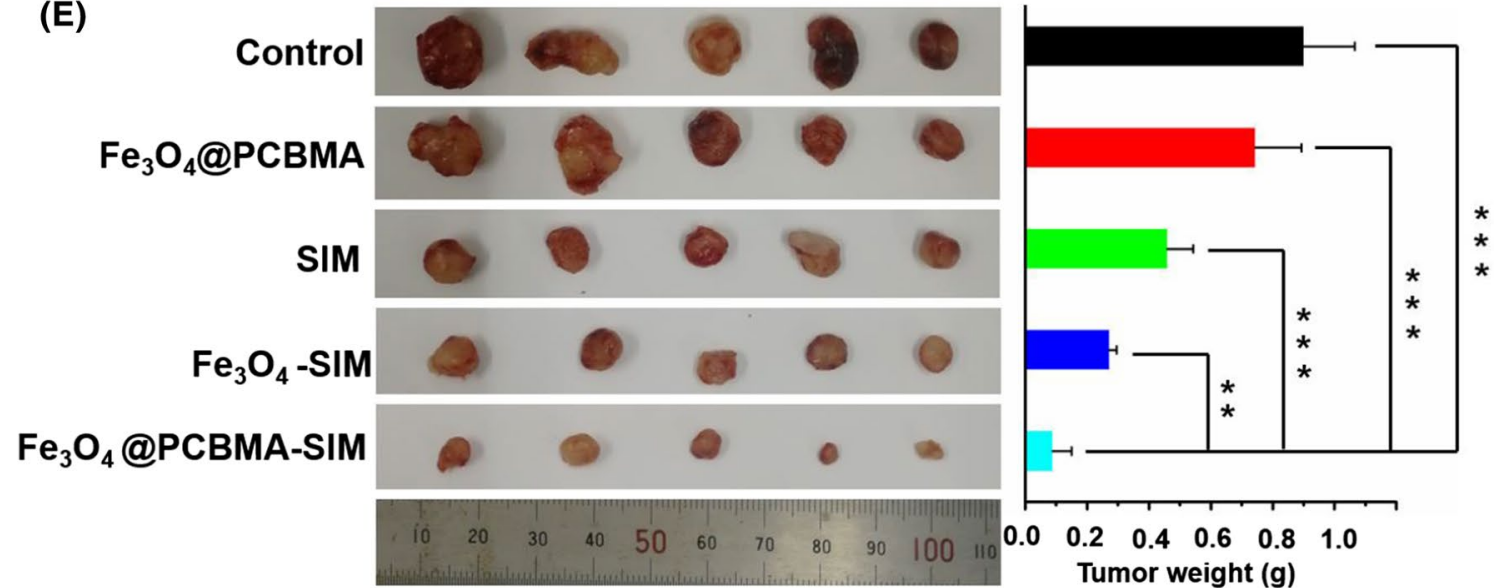

Fig. 5 Biodistribution of $\mathrm{Fe}_{3} \mathrm{O}_{4}$ and $\mathrm{Fe}_{3} \mathrm{O}_{4} @ P C B M A$ nanoparticles after $24 \mathrm{~h}$ injection (A); In vivo blood retention profiles of $\mathrm{Fe}_{3} \mathrm{O}_{4}$ and $\mathrm{Fe}_{3} \mathrm{O}_{4} @$ PCBMA nanoparticles $(1 \mathrm{mg} / \mathrm{mL}, 100 \mu \mathrm{L})(\mathbf{B})$; Tumor growth curves and body weight changes of nanomedicine. Treatments were performed on day 0, 3, 6 and 9 . Error bars indicate the SD $(n=5)(\mathbf{C}, \mathbf{D})$; Photographs (left) and weights (right) of tumors after therapy $(\mathbf{E}){ }^{*} P<0.05 * * P<0.01$ ***P $<0.001$

and $\mathrm{Fe}_{3} \mathrm{O}_{4} @$ PCBMA group with the control group. Moreover, there is no difference between nanoparticles treatment group and control group of the whole blood panel analysis result (Additional file 1: Fig. S10).
Therefore, $\mathrm{Fe}_{3} \mathrm{O}_{4} @$ PCBMA had good biocompatibility without liver and kidney toxicity. 


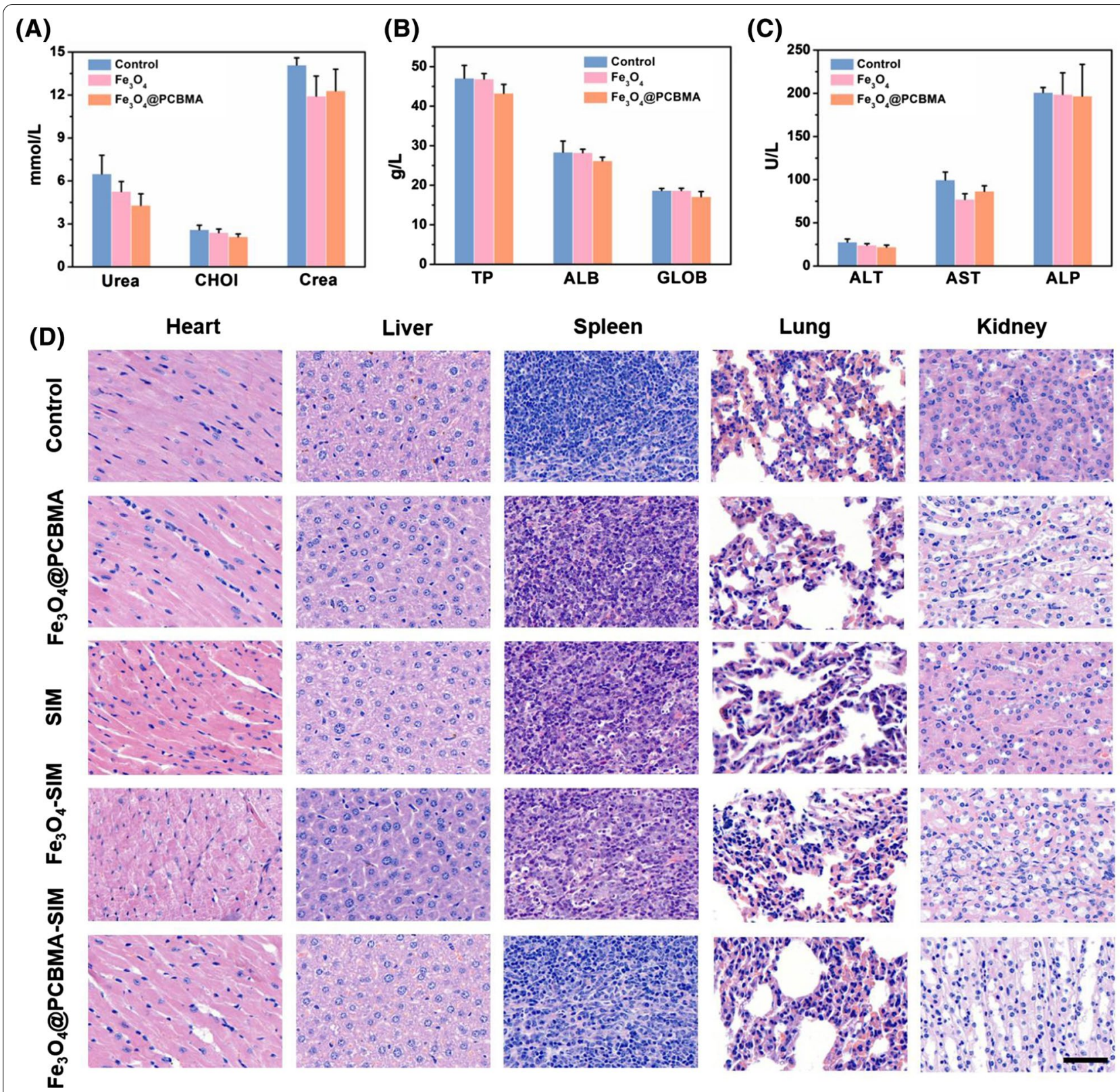

Fig. 6 Blood biochemistry indices of renal and hepatic function including alkaline phosphatase (ALP), alanine aminotransferase (ALT), aspartate aminotransferase (AST) (A); globulin (GLOB), total protein (TP), albumin (ALB) (B) and creatinine (CREA), cholesterol (CHOL), UREA (C); H\&E-stained slices of liver spleen, heart, lung, and kidney from each group (D), Scale bars were 50 mm

\section{Conclusion}

Ferroptosis is a key tumor suppression mechanism. Herein, we presented the ferroptosis nanomedicine by loading simvastatin (SIM), a ferroptosis drugs, into zwitterionic polymer coated of magnetic nanoparticles $\left(\mathrm{Fe}_{3} \mathrm{O}_{4} @ \mathrm{PCBMA}\right)$, thereby improving the therapeutic effect of triple negative breast cancer. This drug delivery platform was demonstrated to have higher toxicity against MDA-MB-231 than MCF-7, which demonstrated that statins could effectively kill triple negative breast cancer. Furthermore, the western blot result illustrated SIM could through inhibit HMGCR to inhibit the mevalonate pathway and deactivate GPX4. With the inherited blood circulation property and ferroptosis effect, $\mathrm{Fe}_{3} \mathrm{O}_{4} @$ PCBMA-SIM was intravenously injected into MDA-MB-231 tumor-bearing mice and 
their treatment efficiency in vivo was evaluated. Our finding highlights that $\mathrm{Fe}_{3} \mathrm{O}_{4} @ P C B M A-S I M$ exhibit an excellent tumor suppression, which will open an avenue of triple negative breast cancer therapy.

\section{Materials and methods}

Synthesis of magnetic nanoparticles and modification $\mathrm{Fe}_{3} \mathrm{O}_{4}$ nanoparticles were prepared by the solvothermal reaction method [38]. Typically, $\mathrm{FeCl}_{3} \cdot 6 \mathrm{H}_{2} \mathrm{O}(0.54 \mathrm{~g}$, $2 \mathrm{mM})$, sodium acetate $(1.2 \mathrm{~g}, 15 \mathrm{mM})$, sodium citrate dihydrate $(0.24 \mathrm{~g}, 1 \mathrm{mM})$ and $20 \mathrm{~mL}$ ethylene glycol mixed and stirred for $30 \mathrm{~min}$. Then transferring the above solution into a three-necked flask $(100 \mathrm{~mL})$ under $200{ }^{\circ} \mathrm{C}$ for $10 \mathrm{~h}$. Finally, the resulting products were dispersed in $50 \mathrm{~mL}$ of deionized water for further use.

Before encapsulating the zwitterionic polymer, $200 \mathrm{mg}$ of $\mathrm{Fe}_{3} \mathrm{O}_{4}, 5 \mathrm{~mL}$ of deionized water, $1.5 \mathrm{~mL}$ of aqueous ammonia solution (28-30\%) was mixed with $35 \mathrm{~mL}$ of ethanol and stirred at $60^{\circ} \mathrm{C}$ for $30 \mathrm{~min}$. Then, $300 \mathrm{mg}$ of MPS was slowly added for another $12 \mathrm{~h}$. Finally, the obtained products were washed three times with ethanol and were named as $\mathrm{Fe}_{3} \mathrm{O}_{4}$-MPS.

\section{Synthesis of carboxybetaine methacrylate (CBMA) monomer}

In a typical recipe [31], 3.14 g of 2-(dimethylamino) ethyl methacrylate was dissolved in $25 \mathrm{~mL}$ of anhydrous acetone, to which $1.5 \mathrm{~mL}$ of $\beta$-propiolactone was added and stirred at $4{ }^{\circ} \mathrm{C}$ for $6 \mathrm{~h}$. The CBMA monomer was obtained by extraction filtration and washed with diethyl ether.

\section{Synthesis of $\mathrm{Fe}_{3} \mathrm{O}_{4} @ P C B M A$}

$\mathrm{Fe}_{3} \mathrm{O}_{4} @ \mathrm{PCBMA}$ were prepared by modified refluxprecipitation polymerization method [39]. Using a typical method, $5 \mathrm{~mL}$ ethanol, $4 \mathrm{mg}$ of AIBN, $20 \mathrm{mg}$ of $\mathrm{Fe}_{3} \mathrm{O}_{4}$-MPS, $5 \mathrm{mg}$ of $\mathrm{BAC}, 95 \mathrm{mg}$ of CBMA monomer and $35 \mathrm{~mL}$ of acetonitrile were added into a threenecked flask and stirred at $90{ }^{\circ} \mathrm{C}$ for $1 \mathrm{~h}$ under $\mathrm{N}_{2}$. Then the resulting product washed with ethanol and deionized water and obtained the composite nanoparticles, denoted as $\mathrm{Fe}_{3} \mathrm{O}_{4} @$ PCBMA.

\section{SIM loading of $\mathrm{Fe}_{3} \mathrm{O}_{4} @ P C B M A\left(\mathrm{Fe}_{3} \mathrm{O}_{4} @ P C B M A-\mathrm{SIM}\right)$}

Firstly, $3 \mathrm{mg}$ of SIM, $1 \mathrm{~mL}$ of deionized water, $2 \mathrm{~mL}$ ethanol and $10 \mathrm{mg}$ of $\mathrm{Fe}_{3} \mathrm{O}_{4} @$ PCBMA were mixed. The above solution was stirred in the dark for $24 \mathrm{~h}$ at room temperature and then vacuum-rotary evaporation to remove solvent and washed with water. Finally, UV-vis spectrophotometer was used to calculate the loading rate of SIM at $238 \mathrm{~nm}$.
SIM releasing from $\mathrm{Fe}_{3} \mathrm{O}_{4} @ \mathrm{PCBMA}-\mathrm{SIM}$

$10 \mathrm{mg}$ of $\mathrm{Fe}_{3} \mathrm{O}_{4} @$ PCBMA-SIM were dispersed into $5 \mathrm{~mL}$ of $\mathrm{GSH}$ with different concentrations $(0,5$, $10 \mathrm{mM})$. Afterwards, the mixed solution was stirred at $37{ }^{\circ} \mathrm{C}$ under dark conditions. After a specific time interval, centrifuge for collecting the supernatant and added another $5 \mathrm{~mL}$ of GSH solution. The SIM releasing amount was calculated according to the UV-vis absorbance value of SIM in the supernatant.

\section{The degradation of $\mathrm{Fe}_{3} \mathrm{O}_{4}$ and $\mathrm{Fe}_{3} \mathrm{O}_{4} @ P C B M A$}

To measure the degradation of nanoparticles, $\mathrm{Fe}_{3} \mathrm{O}_{4}$ and $\mathrm{Fe}_{3} \mathrm{O}_{4} @ \mathrm{PCBMA}(100 \mu \mathrm{g} / \mathrm{mL})$ were placed in a $1.4 \times 10^{4}$ Dalton dialysis bag. Afterwards, the dialysis bag was dip in $200 \mathrm{~mL}$ of PBS ( $\mathrm{pH} 5.0,6.5,7.4)$ with different concentrations of GSH ( $0 \mathrm{mM}, 10 \mathrm{mM})$. And then, $2 \mathrm{~mL}$ of solution was removed and added $2 \mathrm{~mL}$ of PBS with GSH at a certain point in time. ICP-AES was used to measure the amount of Fe.

\section{In vitro cytotoxicity assay}

The cytotoxicity of $\mathrm{Fe}_{3} \mathrm{O}_{4}, \mathrm{Fe}_{3} \mathrm{O}_{4} @$ PCBMA, free SIM, $\mathrm{Fe}_{3} \mathrm{O}_{4}$-SIM and $\mathrm{Fe}_{3} \mathrm{O}_{4} @$ PCBMA-SIM were measured according to previous report [40]. Firstly, MCF-7 and MDA-MB-231 cells were incubated into 96-well plate. After $12 \mathrm{~h}$ incubation, different concentrations of $\mathrm{Fe}_{3} \mathrm{O}_{4}$, $\mathrm{Fe}_{3} \mathrm{O}_{4} @ \mathrm{PCBMA}$, free SIM, $\mathrm{Fe}_{3} \mathrm{O}_{4}$-SIM and $\mathrm{Fe}_{3} \mathrm{O}_{4} @$ PCBMA-SIM were added respectively. Afterwards, CCK- 8 was added after $24 \mathrm{~h}$ of culture to measuring the cell viability.

\section{Cell uptake assay}

Before cell uptake assay, MCF-7 cells and MDA-MB-231 cells were firstly cultured in a $35-\mathrm{mm}$ glass-bottomed dish. Then SIM, Fe $\mathrm{O}_{4} @ \mathrm{PCBMA}, \mathrm{Fe}_{3} \mathrm{O}_{4}-\mathrm{SIM}, \mathrm{Fe}_{3} \mathrm{O}_{4} @$ PCBMA-SIM were added to MCF-7 cells and MDAMB-231 cells $(500 \mu \mathrm{L}, 50 \mu \mathrm{g} / \mathrm{mL})$. Nanoparticle untreated cells were used as control group. After culturing $4 \mathrm{~h}$ at $37^{\circ} \mathrm{C}$, FerroOrange probe $(1 \mu \mathrm{mol} / \mathrm{L})$ was added to each dish for $30 \mathrm{~min}$ at $37{ }^{\circ} \mathrm{C}$ and washed with PBS. Finally, CLSM was used to capture the fluorescence images. (CLSM, Ex: $561 \mathrm{~nm}$, Em: 570-620 nm).

\section{Measuring the reactive oxygen species (ROS) and lipid hydroperoxides (LPO) generation}

To investigate the ROS generation, MCF-7 cells and MDA-MB-231 cells were cultured in a $35-\mathrm{mm}$ glassbottomed dishes. After $24 \mathrm{~h}$ incubation, SIM, $\mathrm{Fe}_{3} \mathrm{O}_{4} @$ PCBMA, $\mathrm{Fe}_{3} \mathrm{O}_{4}$-SIM, $\mathrm{Fe}_{3} \mathrm{O}_{4} @$ PCBMA-SIM suspension $(500 \mu \mathrm{L}, 50 \mu \mathrm{g} / \mathrm{mL})$ were added to each dish and continue cultivation. Then, DCFH-DA (an ROS probe, Ex: $488 \mathrm{~nm}$, Em: $537 \mathrm{~nm}$ ) was added to each dish after $6 \mathrm{~h}$ cultivation for measuring reactive oxygen species (ROS) produced 
by cells. CLSM was used to capture the fluorescence images of cells.

In addition, MCF-7 cells and MDA-MB-231 cells were also seeded in a 6-well plate for the flow cytometry measurement. Similarly, nanoparticles $(500 \mu \mathrm{L}, 50 \mu \mathrm{g} / \mathrm{mL})$ were added to 6-well plate. DCFH-DA (ROS probe) and C11-BODIPY (LPO probe) were used to stain above cells. Finally, all cells were digested for flow cytometry measurement.

\section{In vivo biodistribution and pharmacokinetics of $\mathrm{Fe}_{3} \mathrm{O}_{4} @$ PCBMA}

Before biodistribution and pharmacokinetics of $\mathrm{Fe}_{3} \mathrm{O}_{4} @$ PCBMA nanoparticles, a subcutaneous tumor model of MDA-MB-231 cells was firstly constructed. After the tumor volume reached $60 \mathrm{~mm}^{3}$, the tumor-bearing nude mice were treated with $\mathrm{Fe}_{3} \mathrm{O}_{4}$ and $\mathrm{Fe}_{3} \mathrm{O}_{4} @ P C B M A(2 \mathrm{mg} /$ $\mathrm{mL}$ ) through injected intravenously. After $12 \mathrm{~h}, 24 \mathrm{~h}$ and $48 \mathrm{~h}$, spleen, Heart, kidney, liver, lung and tumor were taken out and dissolved by acid mixture (Vperchloric acid:Vhydrochloric acid=1:4). After diluted with deionized water and filtered through a $0.22 \mathrm{~mm}$ membrane, iron distribution in tissues were measured by ICP-AES.

Similarly, eight Balb/c nude mice (male, 20-22 g) were used to measure the pharmacokinetics of $\mathrm{Fe}_{3} \mathrm{O}_{4} @$ PCBMA. Firstly, $\mathrm{Fe}_{3} \mathrm{O}_{4}$ and $\mathrm{Fe}_{3} \mathrm{O}_{4} @ P C B M A(2 \mathrm{mg} / \mathrm{mL})$ were intravenously injected into female mice $(n=3)$. Then, the whole blood $(30 \mu \mathrm{L})$ was extracted through orbital sinus at different time points $(0,15 \mathrm{~min}$, and 1,2 , $4,8,12,24,48 \mathrm{~h}$ ) and dissolved by acid mixture as above for detected iron distribution in blood.

\section{In vivo therapy of ferroptosis}

To test the therapy of ferroptosis in vivo, MDA-MB-231 cells were injected to subcutaneous of mice to build a tumor model. When the tumor volume reaches about $60 \mathrm{~mm}^{3}$, all mice were randomly divided into five groups $(\mathrm{n}=5)$ for various treatments. Then, mice were treated with PBS, $\mathrm{Fe}_{3} \mathrm{O}_{4} @ \mathrm{PCBMA}, \mathrm{SIM}, \mathrm{Fe}_{3} \mathrm{O}_{4}$-SIM and $\mathrm{Fe}_{3} \mathrm{O}_{4} @$ PCBMA-SIM through injected intravenously. The injected doses of SIM were $4 \mathrm{mg} / \mathrm{kg}$ body weight in each mouse on days $0,3,6$, and 9. Date was collected every other day for recording the change of body weight and tumor volume after drugs treated. After 22 days of therapy, the organs (liver, kidneys, spleen, lung, heart and tumor) of each group mice were taken out and dispersed in $4 \%$ paraformaldehyde for H\&E stain. Finally, TUNEL assay was used to measurement the apoptotic cells in the tumor slices.

\section{Blood biochemistry and routine blood testing}

To measure the safety of nanomedicine, 12 female ICR mice $(25-28 \mathrm{~g})$ were injected intravenously with $100 \mu \mathrm{L}$ of PBS, $\mathrm{Fe}_{3} \mathrm{O}_{4}$ and $\mathrm{Fe}_{3} \mathrm{O}_{4} @$ PCBMA. After $24 \mathrm{~h}$, blood sample from each mouse were taken out and measured the biochemical and routine blood testing indexes to test the safety of nanoparticles.

\section{Statistical analysis}

The data were showed as mean \pm standard deviation. The differences between groups were performed by oneway ANOVA with Dunnett's multiple comparisons test. $\mathrm{P}<0.05$ was considered statistically significant.

\section{Supplementary Information}

The online version contains supplementary material available at https://doi. org/10.1186/s12951-021-01058-1.

Additional file 1: Fig. S1. FT-IR spectra of $\mathrm{Fe}_{3} \mathrm{O}_{4}$ and $\mathrm{Fe}_{3} \mathrm{O}_{4}-\mathrm{MPS}$ nanoparticles. Fig. S2. TEM images of $\mathrm{Fe}_{3} \mathrm{O}_{4} @ P C B M A-S I M$ nanoparticles (A); SEM images of $\mathrm{Fe}_{3} \mathrm{O}_{4} @ P C B M A-S I M$ nanoparticles (B). Fig. S3. DLS diameters of $\mathrm{Fe}_{3} \mathrm{O}_{4} @ P C B M A-\mathrm{SIM}$ nanoparticles dispersed in water, PBS, bovine serum albumin (BSA) and Dulbecco's Modified Eagle Medium (DMEM). Fig. S4. The degradation property of $\mathrm{Fe}_{3} \mathrm{O}_{4}$ nanoparticles dispersed in different concentrations of GSH $(0 \mathrm{mM}$ and $10 \mathrm{mM})$ and $\mathrm{pH}$ values (5.0, 6.5 and 7.4). Fig. S5. Cell viability of ferrous sulfate to MDA-MB-231 cells. Fig. S6. Cell viability of ferrous sulfate to MCF-7 cells. Fig. S7. Biodistribution of $\mathrm{Fe}_{3} \mathrm{O}_{4}$ and $\mathrm{Fe}_{3} \mathrm{O}_{4} @ P C B M A$ nanoparticles after $12 \mathrm{~h}$ injection. Fig. S8. Biodistribution of $\mathrm{Fe}_{3} \mathrm{O}_{4}$ and $\mathrm{Fe}_{3} \mathrm{O}_{4} @ P C B M A$ nanoparticles after $48 \mathrm{~h}$ injection. Fig. S9. TUNEL staining of tumor tissues. Scale bars was $20 \mu \mathrm{m}$. Fig. S10. Whole blood panel analysis of nanoparticle-treated mice at $24 \mathrm{~h}$ post-injection.

\section{Acknowledgements}

The authors greatly appreciate the help from the Public Instruments Center of State Key Laboratory of Molecular Engineering of Polymers for dates test.

\section{Authors' contributions}

$X X Y, H B P$ and WLY designed the research. $X X Y$ conducted the experiments. $X X Y, H B P$ and WLY wrote the manuscript. JT, HBP and WLY analyzed the data and revised the manuscript. $X X Y, R H X$ and $Y B C$ participated in the animal experiments. All authors read and approved the final manuscript.

\section{Funding}

This work was sponsored by the National Natural Science Foundation of China (Grant Nos. 51933002, 51873041, 81902756), the Program of Shanghai Academic Research Leader (20XD1400400), the Open Project of State Key Laboratory of Molecular Engineering of Polymers (No. K2021-19) and Shanghai Sailing Program (Grant No.19Y1439900).

\section{Availability of data and materials}

All data generated or analyzed during this study are included in this published article.

\section{Declarations}

Ethics approval and consent to participate

All animal experiments were carried out with full authorization approved by the ethical committee for animal care of School of Pharmacy, Fudan University (Approval No. 2014-03-YJ-PZQ-01).

Consent for publication

All authors agree to be published.

Competing interests

The authors declare that they have no competing interests. 


\section{Author details}

${ }^{1}$ State Key Laboratory of Molecular Engineering of Polymers \& Department of Macromolecular Science, Fudan University, Shanghai 200433, China. ${ }^{2}$ Department of Materials Science and Engineering, Stanford University, Stanford, CA, USA. ${ }^{3}$ Shanghai General Hospital, Shanghai Jiao Tong University School of Medicine, Shanghai 200080, China. ${ }^{4}$ Institute for Translational Brain Research, Fudan University, Shanghai 200032, China.

Received: 26 July 2021 Accepted: 22 September 2021 Published online: 09 October 2021

\section{References}

1. Sung H, Ferlay J, Siegel RL, Laversanne M, Soerjomataram I, Jemal A, Bray F. Global cancer statistics 2020: GLOBOCAN estimates of incidence and mortality worldwide for 36 cancers in 185 countries. CA-Cancer J Clin. 2021;71:209-49.

2. Zhang T, Liu H, Li L, Guo ZY, Song J, Yang XY, Wan GY, Li RS, Wang YS Leukocyte/platelet hybrid membrane-camouflaged dendritic large pore mesoporous silica nanoparticles co-loaded with photo/chemotherapeutic agents for triple negative breast cancer combination treatment. Bioact Mater. 2021;6:3865-78.

3. Gong Y, Ji P, Yang YS, Xie S, Yu TJ, Xiao Y, Jin ML, Ma D, Guo LW, Pei YC, Chai WJ, Li DQ, Bai F, Bertucci F, Hu X, Jiang YZ, Shao ZM. Metabolic-pathwaybased subtyping of triple-negative breast cancer reveals potential therapeutic targets. Cell Metab. 2021;33:51-64.

4. Holohan C, Van Schaeybroeck S, Longley DB, Johnston PG. Cancer drug resistance: an evolving paradigm. Nat Rev Cancer. 2013;13:714-26.

5. Cao JY, Dixon SJ. Mechanisms of ferroptosis. Cell Mol Life Sci. 2016:73:2195-209.

6. Dixon SJ, Lemberg KM, Lamprecht MR, Skouta R, Zaitsev EM, Gleason CE, Patel DN, Bauer AJ, Cantley AM, Yang WS, Morrison B. Ferroptosis: An irondependent form of nonapoptotic cell death. Cell. 2012;149:1060-72.

7. Wang SF, Li FY, Qiao RR, Hu X, Liao HR, Chen LM, Wu JH, Wu HB, Zhao M, Liu JN, Chen R, Ma XB, Kim D, Sun JH, Davis TP, Chen CY, Tian J, Hyeon $T$, Ling $D$. Arginine-rich manganese silicate nanobubbles as a ferroptosis-inducing agent for tumor-targeted theranostics. ACS Nano. 2018;12:12380-92.

8. Liu T, Liu W, Zhang M, Yu W, Gao F, Li C, Wang SB, Feng J, Zhang XZ. Ferrous-supply-regeneration nanoengineering for cancer-cell-specific ferroptosis in combination with imaging-guided photodynamic therapy. ACS Nano. 2018;12:12181-92.

9. Stockwell BR, Angeli JPF, Bayir H, Bush Al, Conrad M, Dixon SJ, Fulda S, Gascon S, Hatzios SK, Kagan VE, Noel K, Jiang X, Linkermann A, Murphy ME, Overholtzer M, Oyagi A, Pagnussat GC, Park J, Ran Q, Rosenfeld CS, Salnikow K, Tang D, Torti FM, Torti SV, Toyokuni S, Woerpel KA, Zhang DD. Ferroptosis: a regulated cell death nexus linking metabolism, redox biology, and disease. Cell. 2017;171:273-85.

10. An Y, Zhu JD, Liu F, Deng J, Meng X, Liu GQ, Wu HY, Fan AP, Wang Z, Zhao YJ. Boosting the ferroptotic antitumor efficacy via site-specific amplification of tailored lipid peroxidation. ACS Appl Mater Interfaces. 2019:11:29655-66.

11. Viswanathan VS, Ryan MJ, Dhruv HD, Gill S, Eichhoff OM, SeashoreLudlow B, Kaffenberger SD, Eaton JK, Shimada K, Aguirre AJ, Viswanathan SR, Chattopadhyay S, Tamayo P, Yang WS, Rees MG, Chen S, Boskovic ZV, Javaid S, Huang C, Wu X, Tseng YY, Roider EM, Gao D, Cleary JM, Wolpin BM, Mesirov JP, Haber DA, Engelman JA, Boehm JS, Kotz JD, Hon CS, Chen Y, Hahn WC, Levesque MP, Doench JG, Berens ME, Shamji AF, Clemons PA, Stockwell BR, Schreiber SL. Dependency of a therapy-resistant state of cancer cells on a lipid peroxidase pathway. Nature. 2017:547:453-7.

12. Li HY, Shi W, Li XH, Hu YM, Fang Y, Ma HM. Ferroptosis accompanied by -OH generation and cytoplasmic viscosity increase revealed via dualfunctional fluorescence probe. J Am Chem Soc. 2019:141:18301-7.

13. Timmerman LA, Holton T, Yuneva M, et al. Glutamine sensitivity analysis identifies the $\mathrm{xCT}$ antiporter as a common triple-negative breast tumor therapeutic target. Cancer Cell. 2013;24:450-65.

14. Yu MY, Gai CC, Li ZHR, Ding DJ, Zheng J, Zhang WF, LV SJ, Li WT Targeted exosome-encapsulated erastin induced ferroptosis in triple negative breast cancer cells. Cancer Sci. 2019:110:3173-82.
15. Hoque A, Chen $H, X u X C$. Statin induces apoptosis and cell growth arrest in prostate cancer cells. Cancer Epidemiol Biomark Prev. 2008;17:88-94.

16. Yin Y, Liu L, Zhao Z, Yin L, Bauer N, Nwaeburu CC, Gladkich J, Gross W, Hackert T, Sticht C, Gretz N, Strobel O, Herr I. Simvastatin inhibits sonic hedgehog signaling and stemness features of pancreatic cancer. Cancer Lett. 2018;426:14-24.

17. Goldstein JL, Brown MS. A century of cholesterol and coronaries: from plaques to genes to statins. Cell. 2015;161:161-72.

18. Yu HT, Guo PY, Xie XZ, Wang Y, Chen G. Ferroptosis, a new form of cell death, and its relationships with tumourous diseases. J Cell Mol Med. 2017;21:648-57.

19. Yang WS, Stockwell BR. Ferroptosis: death by lipid peroxidation. Trends Cell Biol. 2016:26:165-76.

20. Angeli JPF, Schneider M, Proneth $B$, Tyurina YY, Tyurin VA, Hammond VJ, Herbach N, Aichler M, Walch A, Eggenhofer E, Basavarajappa D, Radmark O, Kobayashi S, Seibt T, Beck H, Neff F, Esposito I, Wanke R, Forster H, Yefremova O, Heinrichmeyer M, Bornkamm GW, Geissler EK, Thomas SB, Stockwell BR, O'Donnell VB, Kagan VE, Schick JA, Conrad M. Inactivation of the ferroptosis regulator Gpx4 triggers acute renal failure in mice. Nat Cell Biol. 2014;16:1180-91.

21. Warner GJ. Inhibition of selenoprotein synthesis by selenocysteine tRNA[Ser]Sec lacking isopentenyladenosine. J Biol Chem. 2000;275:28110-9.

22. Liu M, Liu B, Liu QQ, Du KK, Wang ZF, He NY. Nanomaterial-induced ferroptosis for cancer specific therapy. Coord Chem Rev. 2019;382:160-80.

23. Wilhelm S, Tavares AJ, Dai Q, Ohta S, Audet J, Dvorak HF, Chan WCW. Analysis of nanoparticle delivery to tumours. Nat Rev Mater. 2016;1:1-12.

24. Jiang Q, Liu Y, Guo RR, Yao XX, Sung S, Pang ZQ, Yang WL. Erythrocytecancer hybrid membrane-camouflaged melanin nanoparticles for enhancing photothermal therapy efficacy in tumors. Biomaterials. 2019;192:292-308.

25. Liu J, Sun ZK, Deng YH, Zou Y, Li CY, Guo XH, Xiong LQ, Gao Y, Li FY, Zhao DY. Highly water-dispersible biocompatible magnetite particles with low cytotoxicity stabilized by citrate groups. Angew Chem Int Ed. 2009:48:5875-9.

26. Zhang L, Xue H, Cao ZQ, Keefe A, Wang JN, Jiang SY. Multifunctional and degradable zwitterionic nanogels for targeted delivery, enhanced MR imaging, reduction-sensitive drug release, and renal clearance. Biomaterials. 2011;32:4604-8.

27. Peng SJ, Ouyang BS, Men YZ, Du Y, Cao YB, Xie RH, Pang ZQ, Shen S, Yang WL. Biodegradable zwitterionic polymer membrane coating endowing nanoparticles with ultra-long circulation and enhanced tumor photothermal therapy. Biomaterials. 2020;231:119680.

28. Wang F, Zhang YT, Yang P, Jin S, Yu M, Guo J, Wang CC. Fabrication of polymeric microgels using reflux-precipitation polymerization and its application for phosphoprotein enrichment. J Mater Chem B. 2014;2:2575-82.

29. Zhai SY, Ma YH, Chen YY, Li D, Cao J, Liu YJ, Cai MT, Xie XX, Chen YW, Luo $\mathrm{XL}$. Synthesis of an amphiphilic block copolymer containing zwitterionic sulfobetaine as a novel $\mathrm{pH}$-sensitive drug carrier. Polym Chem. 2014;5:1285-97.

30. Barry P, Vatsiou A, Spiteri I, Nichol D, Cresswell GD, Acar A, Trahearn N, Hrebien S, Garcia-Murillas I, Chkhaidze K, Ermini L, Huntingford IS, Cottom H, Zabaglo L, Koelble K, Khalique S, Rusby JE, Muscara F, Dowsett M, Maley CC, Natrajan R, Yuan Y, Schiavon G, Turner N, Sottoriva A. The spatiotemporal evolution of lymph node spread in early breast cancer. Clin Cancer Res. 2018;24:4763-70.

31. Wang Y, Tang M. Corrigendum to PM2.5 induces ferroptosis in human endothelial cells through iron overload and redox imbalance. Environ Pollut (Barking, Essex: 1987). 2021;276:113640.

32. Guo SD, Yao XX, Jiang $Q$, Wang K, Zhang YY, Peng HB, Yang WL. Dihydroartemisinin-loaded magnetic nanoparticles for enhanced chemodynamic therapy. Front Pharmacol. 2020;11:226.

33. Lucky SS, Idris NM, Li ZQ, Huang K, Soo KC, Zhang Y. Titania coated upconversion nanoparticles for near-infrared light triggered photodynamic therapy. ACS Nano. 2015;9:191-205.

34. Mandal CC, Ghosh-Choudhury N, Yoneda T, Choudhury GG. Simvastatin prevents skeletal metastasis of breast cancer by an antagonistic interplay between p53 and CD44. J Biol Chem. 2011;286:11314-27.

35. Hayano M, Yang WS, Corn CK, Pagano NC, Stockwell BR. Loss of cysteinyltRNA synthetase (CARS) induces the transsulfuration pathway and 
inhibits ferroptosis induced by cystine deprivation. Cell Death Differ. 2016;2:270-8.

36. Reed JC, Pellecchia M. Ironing out cell death mechanisms. Cell. 2012;149:963-5.

37. Chen G, Roy I, Yang C, Prasad PN. Nanochemistry and nanomedicine for nanoparticle-based diagnostics and therapy. Chem Rev. 2016;116:2826-85.

38. Deng H, Li XL, Peng Q, Wang X, Chen JP, Li YD. Monodisperse magnetic single-crystal ferrite microspheres. Angew Chem Int Ed. 2005;44:2782-5.

39. Yao XX, Yang P, Jin ZK, Jiang Q, Guo RR, Xie RH, He QJ, Yang WL. Multifunctional nanoplatform for photoacoustic imaging-guided combined therapy enhanced by CO induced ferroptosis. Biomaterials. 2019;197:268-83.

40. Ryu JH, Jiwpanich S, Chacko R, Bickerton S, Thayumanavan S. Surfacefunctionalizable polymer nanogels with facile hydrophobic guest encapsulation capabilities. J Am Chem Soc. 2010;132:8246.

\section{Publisher's Note}

Springer Nature remains neutral with regard to jurisdictional claims in published maps and institutional affiliations.
Ready to submit your research? Choose BMC and benefit from:

- fast, convenient online submission

- thorough peer review by experienced researchers in your field

- rapid publication on acceptance

- support for research data, including large and complex data types

- gold Open Access which fosters wider collaboration and increased citations

- maximum visibility for your research: over 100M website views per year

At BMC, research is always in progress.

Learn more biomedcentral.com/submissions 